\title{
Acceleration of Sports Recovery with Glutamine Supplementation in Vertical Jump and Badminton Smash Velocity
}

\author{
Himawan Wismanadi ${ }^{1, *}$ Fatkur Rohman Kafrawi ${ }^{2,}$ Soni Sulistyarto ${ }^{3,}$ Abdul Aziz \\ Hakim $^{4}$, Afif Rusdiawan ${ }^{5}$, Lutfhi Abdil Khuddus ${ }^{6}$ \\ 1,2,3,4,5,6 Department of Health Education and Recreation, Universitas Negeri Surabaya, Indonesia \\ ${ }^{*}$ Corresponding author. Email: himawanwismanadi@unesa.ac.id
}

\begin{abstract}
The purpose of this study was to determine the effect of glutamine supplementation on the ability of vertical jump and smash velocity after badminton's jumping smash. The research used a pre-post two-group design using 20 trained male athletes from the State University of Surabaya. The research sample was divided into two groups: the Placebo (PLA) group, which was given exercise + mineral water, and the glutamine (GLU) group, which was given training + glutamine supplement. The movement provided is to do a jumping smash for 20 repetitions, ten sets with 30 -second intervals. Glutamine dose of $0.4 \mathrm{gram} / \mathrm{Kg} \mathrm{BW}$ was given 1 hour after jumping smash activity, 24 hours, and 48 hours after jumping smash activity (3 times). The data collection instrument was a vertical jump test using an MD jump, while the smash velocity was measured using a Bushnell 101922 radar gun. Independent sample t-test showed significant $\Delta$ pre-post2 and $\Delta$ post1-post 2 on the vertical jump variable $(\mathrm{p}<0.05)$. On the smash velocity variable, effective results were demonstrated in $\Delta$ pre-post3 and $\Delta$ post1-post3. In conclusion, glutamine supplementation for three days could improve the vertical jump ability at 48 hours and smash velocity at 72 hours.
\end{abstract}

Keywords: Badminton, Glutamine, Vertical jump, Smash velocity, Recovery.

\section{INTRODUCTION}

Muscle recovery after exercise is essential to maintain performance due to muscle fatigue [1]. In many sports competitions, rest periods between rounds and rapid muscle recovery are crucial factors supporting sports performance [2].

Muscle fatigue can be defined as any activity that reduces a person's maximal force or power [3]. Several metabolic factors that influence muscle fatigue are the accumulation of metabolic hydrogen $(\mathrm{H}+)$ ions, lactate, inorganic phosphate $(\mathrm{Pi})$, reactive oxygen species (ROS), heat shock protein (HSP), and orosomucoid (ORM) after exercise [4].

Badminton is a sport with high explosives interspersed with periods of rest [5]. In this sport, many rallies last less than 10 seconds, with rapid, repetitive, intense movements of short duration [6]. Among many badminton strokes, jumping smash is an indispensable hit to get points to win the game. The dominant stroke in doubles matches is the forehand jumping smash, accounting for $1 / 5$ of the attack [7]. Muscle contractions carried out by jumping smash continuously will reduce the strength and speed of muscle contractions, causing fatigue [8][9]. Fatigue due to exercise can be reduced by providing rest time [10]. However, coaches use many strategies to delay fatigue and speed up recovery after training, such as regulating sports nutrition [11]. One of the supplements that trainers and athletes often use is glutamine [12]. Glutamine increases glycogen synthesis [13]. Glutamine can also reduce muscle damage and function as an anti-inflammatory and increase glutathione (GSH) synthesis [14][15]. Sports performance is closely related to muscle protein synthesis [16]. Glutamine supplementation increases athletes' performance in terms of power, vertical jump height, and overall muscle strength due to increased muscle mass [17]. Apart from the effect of glutamine on improving the performance of athletes, it is necessary to conduct an assessment through this study by looking at the performance of badminton athletes on smash speed and vertical jump ability after consuming glutamine.

\section{METHODS}

This study included an experimental study with a sample of 20 male students at the State University of 
Surabaya who were trained, aged 18-22 years, had normal BMI and had no muscle injuries. The research sample was divided into two groups by purposive sampling: the Placebo (PLA) group, which was given exercise + mineral water, and the glutamine (GLU) group, which was given training + glutamine supplement. The movement provided is to do a jumping smash for 20 repetitions, ten sets with 30 -second intervals. A 0.4 gram $/ \mathrm{kg}$ BW glutamine dose was given 1 hour after jumping smash activity, 24 hours, and 48 hours after jumping smash activity (3 times administration) [18].

Data were collected four times, before treatment (pretest), 24 hours after jumping smash (posttest 1), 48 hours after jumping success (posttest 2), and 72 hours after jumping success (posttest 4). The data collection instrument was a vertical jump test using an MD jump with $\mathrm{cm}$ units, carried out three times, and the best value was taken. While the smash speed was measured using a Bushnell 101922 radar gun manufactured in Germany with units of $\mathrm{km} /$ hour [19].

Data were analyzed using a descriptive test, normality test, paired t-test, and independent-sample t-test. Data analysis was performed using SPSS 20.

\section{RESULTS AND DISCUSSION}

\subsection{Results}

A total of 20 male student trained at Universitas Negeri Surabaya (mean \pm SD; age: $19.55 \pm 1.36$ years, height: $167.24 \pm 3.55 \mathrm{~cm}$, weight: $66.18 \pm 2.70 \mathrm{~kg}$, BMI: $23.67 \pm 0.96 \mathrm{~kg} / \mathrm{m} 2$ ) participated in this study. Descriptive analysis in the form of mean \pm SD of research variables in each group is presented in table 1

Table 1. Vertical jump and smash velocity in both groups

\begin{tabular}{|c|c|c|c|c|c|}
\hline \multicolumn{2}{|l|}{ Variable } & PLA $(\mathbf{N}=\mathbf{1 0})$ & \multicolumn{2}{|l|}{ Variable } & GLU (N=10) \\
\hline \multirow[t]{3}{*}{ Vertical jump (cm) } & Pre & $63.80 \pm 5.37^{\mathrm{a}}$ & \multirow[t]{3}{*}{ Vertical jump (cm) } & Pre & $63.40 \pm 4.20^{\mathrm{a}}$ \\
\hline & Post1 & $58.80 \pm 5.05^{b}$ & & Post1 & $57.50 \pm 4.86^{b}$ \\
\hline & Post3 & $61.90 \pm 5.24^{\mathrm{a}, \mathrm{b}, \mathrm{c}}$ & & Post3 & $63.10 \pm 4.84^{\mathrm{a}, \mathrm{c}}$ \\
\hline \multirow[t]{4}{*}{ Smash velocity $(\mathrm{km} / \mathrm{h})$} & Pre & $155.64 \pm 7.93^{\mathrm{a}}$ & \multirow[t]{4}{*}{ Smash velocity $(\mathrm{km} / \mathrm{h})$} & Pre & $157.39 \pm 5.74^{\mathrm{a}}$ \\
\hline & Post1 & $140.45 \pm 7.53^{b}$ & & Post1 & $142.37 \pm 3.90^{b}$ \\
\hline & Post2 & $144.28 \pm 8.78^{\mathrm{c}}$ & & Post2 & $147.18 \pm 5.51^{\mathrm{c}}$ \\
\hline & Post3 & $148.81 \pm 8.88^{\mathrm{a}, \mathrm{c}}$ & & Post3 & $155.35 \pm 4.31^{\mathrm{a}}$ \\
\hline
\end{tabular}

Data are presented as mean (SD), PLA= Placebo group; GLU= Glutamine group; Pre= data taken before jumping smash; Post $1=$ data taken 24 hours after jumping success; Post $2=$ data taken 48 hours after jumping success; Post $3=$ data taken 72 hours after jumping success, significant $\mathrm{p}<0.05$. Significant difference if different letters $(\mathrm{a}, \mathrm{b}, \mathrm{c}, \mathrm{d})$.

Paired t-test was carried out in Table 1 above to determine the difference in the variable's value after being given treatment. The paired t-test showed a decrease in the value of the vertical jump in the PLA and GLU groups after doing the jumping smash exercise. The difference lies at 48 hours, where the PLA group showed no significant difference ( $p>0.05)$ while the GLU group showed significantly different results $(\mathrm{p}<0.05)$.

However, at 48 and 72 hours, there was a gradual increase in both groups.
The paired t-test also showed decreased results in both groups on the smash velocity variable after the jumping smash exercise. However, it gradually increased at 48 and 72 hours in both groups. However, there was also a difference in results. At 72 hours, the PLA group showed no significant difference between 48 hours, while in the GLU group, there was a substantial difference between 48 and 72 hours. More details can be seen in fig. 1 .

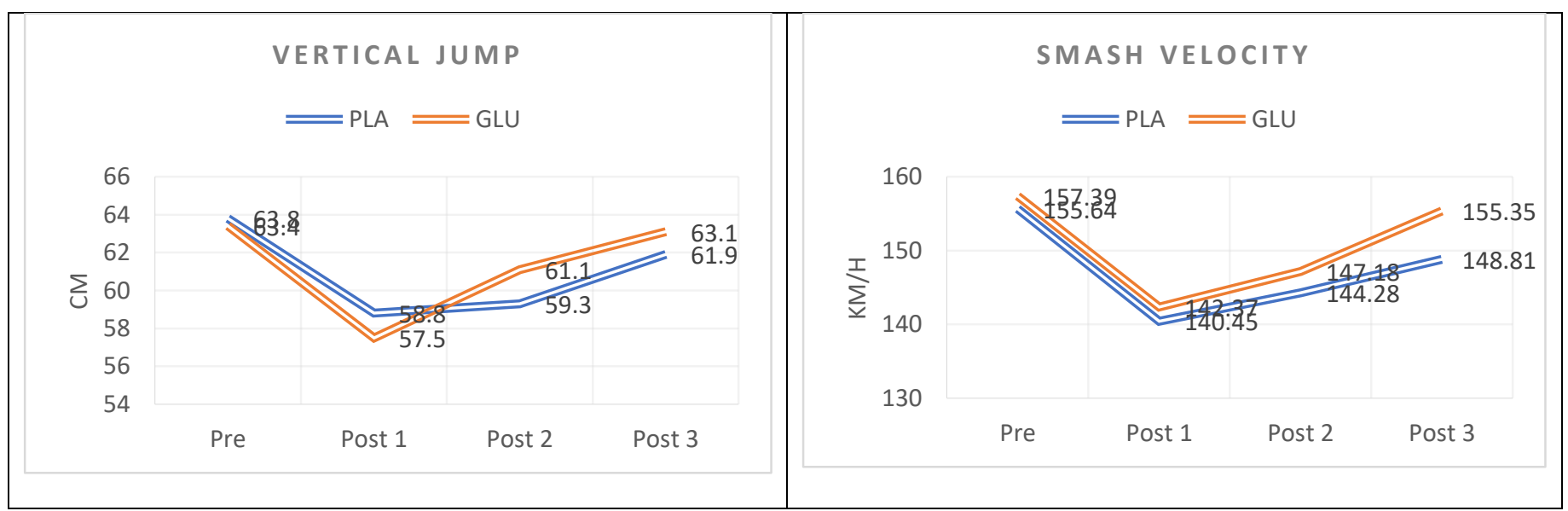

Figure 1 Results of vertical jump and smash velocity before and after treatment in PLA and GLU groups 
Table 2. Difference of vertical jump and smash velocity after taking glutamine supplement

\begin{tabular}{|c|c|c|c|c|}
\hline Variable & & PLA (N=10) & GLU (N=10) & P (sig) \\
\hline \multirow{4}{*}{ Vertical jump } & $\Delta$ pre-post1 & $-5.00 \pm 1.05$ & $-5.90 \pm 1.91$ & 0.209 \\
\cline { 2 - 5 } & $\Delta$ pre-post2 & $-4.50 \pm 0.97$ & $-2.30 \pm 1.61$ & $0.000^{*}$ \\
\cline { 2 - 5 } & $\Delta$ pre-post3 & $-1.90 \pm 7.67$ & $-0.30 \pm 5.50$ & 0.598 \\
\cline { 2 - 5 } & $\Delta$ post1-post2 & $0.50 \pm 1.27$ & $3.60 \pm 2.46$ & $0.002^{*}$ \\
\cline { 2 - 5 } & $\Delta$ post1-post3 & $3.10 \pm 6.81$ & $5.60 \pm 6.24$ & 0.403 \\
\cline { 2 - 5 } & $\Delta$ post2-post3 & $2.60 \pm 7.59$ & $2.00 \pm 6.31$ & 0.850 \\
\hline Smash velocity & $\Delta$ pre-post1 & $-15.19 \pm 5.01$ & $-15.01 \pm 4.92$ & 0.937 \\
\cline { 2 - 5 } & $\Delta$ pre-post2 & $-11.36 \pm 4.82$ & $-10.21 \pm 3.49$ & 0.548 \\
\cline { 2 - 5 } & $\Delta$ pre-post3 & $-6.83 \pm 4.72$ & $-2.04 \pm 3.16$ & $0.016^{*}$ \\
\cline { 2 - 5 } & $\Delta$ post1-post2 & $3.83 \pm 2.83$ & $4.81 \pm 4.15$ & 0.547 \\
\cline { 2 - 5 } & $\Delta$ post1-post3 & $8.36 \pm 2.78$ & $8.97 \pm 4.86$ & $0.018^{*}$ \\
\cline { 2 - 5 } & $\Delta$ post2-post3 & $4.53 \pm 1.49$ & & 0.056 \\
\hline
\end{tabular}

The delta value was the difference between the test results before doing the jumping smash and giving glutamine 24 hours, 48 hours, and 72 hours after doing the jumping smash. The aim was to compare these differences between the PLA and the GLU groups using an independent sample t-test. Table II shows that the vertical jump data differs significantly in delta two and delta $4(\mathrm{p}<0.05)$. A significant difference in delta 2 and 4 means that the administration of glutamine supplements affects the vertical jump at 48 hours of jumping smash exercise.

The smash velocity variable showed significantly different results in delta three and $5(\mathrm{p}<0.05)$. It means that the supplement of glutamine affects the smash velocity at 72 hours after the jumping smash exercise.

\subsection{Discussion}

The results explained that as much as 20 repetitions, ten sets with 30-second intervals, the jumping smash exercise affects the ability at 24 and 48 hours. However, at 72 hours, the vertical jump and smash velocity abilities gradually return to their initial skills before hitting the jumping smash. In their research, Sasaki et al. (2018) stated that the repetition of vertical jumps when performing a jumping smash would cause muscle damage [20]. Damaged muscles will decrease the sheer jump ability [21], like the results of research by Rusdiana et al. (2020), which showed the results of the vertical jump ability that decreased after hitting a jumping smash [19].

It also happened to the smash velocity variable. Table I showed a decrease in smash speed after 20 repetitions of a jumping smash, ten sets with 30-second intervals at 24 and 48 hours. This follows Rusdiana et al. (2020) research, which showed a faster smash velocity in non-athlete fatigue than athlete fatigue [19].

The independent sample t-test in table II showed that glutamine administration affects the vertical jump results 48 hours after hitting the jumping smash. In their research, Hakimi et al. (2012) stated that the vertical jump results were better in the group given glutamine than placebo [22].
Glutamine increases glycogen synthesis and stimulates muscle protein synthesis to repair muscle damaged by exercise [23].

Our findings showed that glutamine supplementation improved smash velocity at 72 hours. The addition of 20 grams of protein to the daily diet increased the athlete's power. This is because almost one-third of the amino acid profile in protein is used for glutamine synthesis in muscle [24]. Glutamine can prevent the accumulation of ammonia [25]. Ammonia produced during exercise will decrease ATP and glycogen stores [26]. With glutamine supplementation, ammonia accumulation can be reduced because glutamine accelerates the transport of ammonia to the liver for metabolism and the kidneys for excretion [27].

The increase in muscle mass due to glutamine supplementation also increases the strength of muscle contraction, affecting its power [28]. The power ability positively correlates with the smash velocity at the time of the jumping smash [29].

\section{CONCLUSION}

Glutamine supplementation of 0.4 gram $/ \mathrm{Kg}$ BW for three days can improve the vertical jump at 48 hours, while the smash velocity is improved at 72 hours. So for consideration of accelerating muscle recovery, trainers or athletes can provide glutamine supplements by estimating the administration time because the recovery effect due to glutamine supplementation has a different time in each muscle and depends on the movement performed.

\section{ACKNOWLEDGMENTS}

Thank you to the Universitas Negeri Surabaya badminton athletes who are willing to be research subjects. Thanks also to Universitas Negeri Surabaya's non-tax revenues for funding this research.

\section{REFERENCES}

[1] M. J. Lehmann et al., "Training and overtraining: An 
overview and experimental results in endurance sports," J. Sports Med. Phys. Fitness, vol. 37, no. 1, pp. 7-17, 1997.

[2] A. Mika, P. Mika, B. Fernhall, and V. B. Unnithan, "Comparison of recovery strategies on muscle performance after fatiguing exercise," Am. J. Phys. Med. Rehabil., vol. 86, no. 6, pp. 474-481, 2007, DOI: 10.1097/PHM.0b013e31805b7c79.

[3] S. C. Gandevia, "Spinal and supraspinal factors in human muscle fatigue," Physiol. Rev., vol. 81, no. 4, pp. 1725-1789, 2001, DOI: 10.1152/physrev.2001.81.4.1725.

[4] J.-J. Wan, Z. Qin, P.-Y. Wang, Y. Sun, and X. Liu, "Muscle fatigue: general understanding and treatment," Exp. Mol. Med., p. 384, 2017, DOI: 10.1038/emm.2017.194.

[5] R. Jeyaraman, E. District, and T. Nadu, "Prediction of playing ability in Badminton from selected anthropometrical physical and physiological characteristics among intercollegiate players," Ijajr, vol. 2, no. 5, p. 11, 2012.

[6] Y. Le Mansec, J. Perez, Q. Rouault, J. Doron, and M. Juneau, "Impaired performance of the smash stroke in badminton induced by muscle fatigue," Int. J. Sports Physiol. Perform., vol. 15, no. 1, pp. 52-59, 2020, DOI: 10.1123/ijspp.2018-0697.

[7] S. K. Park, W. K. Lam, S. Yoon, K. K. Lee, and J. Ryu, "Effects of forefoot bending stiffness of badminton shoes on agility, comfort perception and lower leg kinematics during typical badminton movements," Sport. Biomech., vol. 16, no. 3, pp. 374-386, 2017, DOI: 10.1080/14763141.2017.1321037.

[8] C. H. Ooi et al., "Physiological characteristics of elite and sub-elite badminton players," J. Sports Sci., vol. 27, no. 14, pp. 1591-1599, 2009, DOI: $10.1080 / 02640410903352907$.

[9] Y. Le Mansec, B. Pageaux, A. Nordez, S. Dorel, and M. Juneau, "Mental fatigue alters the speed and the accuracy of the ball in table tennis," J. Sports Sci., vol. 36, no. 23, pp. 2751-2759, 2018, DOI: 10.1080/02640414.2017.1418647.

[10] B. Norman, "Inosine monophosphate accumulation in energy-deficient human skeletal muscle about substrate availability, fiber types and AMP deaminase activity," Scand. J. Clin. Lab. Invest., vol. 55, no. 8, pp. 733-741, 1995, DOI: $10.3109 / 00365519509075404$.

[11] M. Amann, S. K. Sidhu, J. C. Weavil, T. S. Mangum, and M. Venturelli, "Autonomic responses to exercise: Group III/IV muscle afferents and fatigue," Auton. Neurosci. Basic Clin., vol. 188, pp. 19-23, 2015, DOI: 10.1016/j.autneu.2014.10.018.

[12] A. Ramezani Ahmadi, E. Rayyani, M. Bahreini, and A.
Mansoori, "The effect of glutamine supplementation on athletic performance, body composition, and immune function: A systematic review and a meta-analysis of clinical trials," Clin. Nutr., vol. 38, no. 3, pp. 10761091, 2019, DOI: 10.1016/j.clnu.2018.05.001.

[13] A. C. Coelho et al., "Instantaneous quantification of skeletal muscle activation, power production, and fatigue during cycle ergometry," J. Appl. Physiol., vol. 118, no. 5, pp. 646-654, 2015, DOI: 10.1152/japplphysiol.00948.2014.

[14] V. F. Cruzat, M. M. Rogero, and J. Tirapegui, "Effects of supplementation with free glutamine and the dipeptide alanyl-glutamine on parameters of muscle damage and inflammation in rats submitted to prolonged exercise," Cell Biochem. Funct., vol. 28, no. 1, pp. 24-30, 2010, DOI: 10.1002/cbf.1611.

[15] É. R. Petry, V. F. Cruzat, T. G. Heck, J. S. M. Leite, P. I. Homem De Bittencourt, and J. Tirapegui, "Alanylglutamine and glutamine plus alanine supplements improve skeletal redox status in trained rats: Involvement of heat shock protein pathways," Life Sci., vol. 94, no. 2, pp. 130-136, 2014, DOI: 10.1016/j.lfs.2013.11.009.

[16] S. M. Pasiakos, T. M. McLellan, and H. R. Lieberman, "The Effects of Protein Supplements on Muscle Mass, Strength, and Aerobic and Anaerobic Power in Healthy Adults: A Systematic Review," Sport. Med., vol. 45, no. 1, pp. 111-131, 2015, DOI: 10.1007/s40279-014-02422.

[17] M. Lehmkuhl et al., "The Effects of 8 Weeks of Creatine Monohydrate and Glutamine Supplementation on Body Composition and Performance Measures," J. Strength Cond. Res., vol. 17, no. 3, pp. 425-38, 2003, DOI: DOI:10.1519/1533-4287(2003)017.

[18] A. Rusdiawan and T. Taufikkurrachman, "Effect of Glutamine Supplement Administration on the Reduction of Muscular Fatigue Post-Eccentric Exercise," Folia Medica Indones., vol. 55, no. 4, p. 275, 2020, DOI: 10.20473/fmi.v55i4.17320.

[19] A. Rusdiana, H. Subarjah, I. Imanudin, Y. Kusdinar, A. M. Syahid, and T. Kurniawan, "Effect of Fatigue on Biomechanical Variable Changes in Overhead Badminton Jump Smash," Ann. Appl. Sport Sci., vol. 8, no. 1, pp. 1-9, 2020, doi: 10.29252/aassjournal.895.

[20] S. Sasaki, Y. Nagano, and H. Ichikawa, "Loading differences in single-leg landing in the forehand- and backhand-side courts after an overhead stroke in badminton: A novel tri-axial accelerometer research," J. Sports Sci., vol. 36, no. 24, pp. 2794-2801, 2018, DOI: 10.1080/02640414.2018.1474535.

[21] C. Byrne and R. Eston, "The effect of exercise-induced muscle damage on isometric and dynamic knee extensor strength and vertical jump performance," J. Sports Sci., 
vol. 20, no. 5, pp. 417-425, 2002, DOI: $10.1080 / 026404102317366672$.

[22] M. Hakimi, M. A. Mohamadi, and Z. Ghaderi, "The effects of glutamine supplementation on performance and hormonal responses in non-athlete male students during eight-week resistance training," J. Hum. Sport Exerc., vol. 7, no. 4, pp. 770-782, 2012, doi: 10.4100/jhse.2012.74.05.

[23] G. R. Steele, J. Lambourne, A. Casey, I. A. Macdonald, and P. L. Greenhaff, "Stimulatory effect of insulin on creatine accumulation in human skeletal muscle," Am. J. Physiol. - Endocrinol. Metab., vol. 275, no. 6 38-6, 1998, DOI: 10.1152/ajpendo.1998.275.6.e974.

[24] L. M. Hidayah and L. Muniroh, "Hubungan Tingkat Kecukupan Energi, Protein Dan Indeks Massa Tubuh (Imt) Dengan Power Atlet Beladiri," Media Gizi Indones., vol. 12, no. 1, p. 34, 2018, doi: 10.20473/mgi.v12i1.34-39.

[25] I. Fister, I. Fister, and D. Fister, "Sports Nutrition," Adapt. Learn. Optim., vol. 22, no. i, pp. 247-277, 2019, DOI: 10.1007/978-3-030-03490-0_11.

[26] J. Finsterer, "Biomarkers of peripheral muscle fatigue during exercise," BMC Musculoskelet. Disord., vol. 13, pp. 1-13, 2012, DOI: 10.1186/1471-2474-13-218.

[27] A. Yule Coqueiro et al., "Effects of Glutamine and Alanine Supplementation on Central Fatigue Markers in Rats Submitted to Resistance Training," DOI: 10.3390/nu10020119.

[28] G. C. Phillips, "Glutamine: The nonessential amino acid for performance enhancement," Curr. Sports Med. Rep., vol. 6, no. 4, pp. 265-268, 2007, DOI: 10.1007/s11932007-0043-6.

[29] R. Hermansyah, I. Imanudin, and, Badruzaman, "Hubungan Power Otot Lengan Dan Koordinasi Dengan Kecepatan Dan Ketepatan Smash Dalam Cabang Olahraga Bulutangkis," J. Terap. Ilmu Keolahragaan, vol. 2, no. 1, p. 44, 2017, doi: 10.17509/jtikor.v2i1.5355. 